\title{
Economic organization and liberalization of the electricity industry
}

\author{
In search of conceptualization
}

\author{
Maarten J Arentsen and Rolf W Künneke \\ Faculty of Public Administration and Public Policy, University of Twente, PO Box 217, 7500 AE Enschede, The \\ Netherlands
}

\begin{abstract}
In this article a theoretical conceptualization of the liberalization of the electricity industry is developed. Three pure and six mixed coordination systems are identified. The main distinguishing factor is the choice of one of three different allocation systems (the price mechanism, voluntary agreement and governmental hierarchical authority) as a dominant or additional system. Based on this conceptualization, it is possible to operationalize the concept of liberalization, to distinguish it from the notions of privatization and regulation, and to model the relation between different sectoral organizations and different types of governmental regulation. The classification scheme is illustrated by applying it to four countries (the Netherlands, Germany, England and Wales, and France). The concept turns out to be useful in describing different organizational structures in the electricity industry, and in specifying the different degrees of liberalization already realized. Different national policy priorities are identified, and it is demonstrated that liberalization takes on very different meanings in different national settings. By taking account of these national approaches, future liberalization policies can be assessed. Copyright $(\mathcal{O} 1996$ Elsevier Science Ltd.
\end{abstract}

Keywords: Industrial organization; Electricity market; Regulation

In many European countries the electricity industry, traditionally dominated by the public sector, is being reformed. In these countries a search for adaptive organizational structures is under way to enable the industry to achieve optimal performance. The challenge is to find effective and efficient ways of integrating the public tasks of the industry with the workings of the market. Many of these countries are currently developing their own ways of doing this, based on the existing structures of their electricity industries. The challenge for scientists is to develop concepts which allow empirical comparisons between these reforms. In this paper we propose just such a conceptualization, based on the theories of neo- and new institutional economics. ${ }^{1}$

The central issue to be tackled is how to conceptualize the organizational structure and dynamics of the industry, taking into account the utility companies' public tasks. Traditionally, public sector dominance of the industry derived

'See for example Eggertsson (1990), North (1981) and Williamson (1975). its legitimacy from these public tasks, but this public sector dominance has been questioned for a number of reasons. ${ }^{2}$ Supporters of liberalization policies expect, among other benefits, that these will lead to increased economic welfare at the macroeconomic level. Whether liberalization will have this hypothetical effect is an empirical question, now the subject of research in many European countries, including the Netherlands. A necessary first step towards validating this hypothesis is to construct a conceptualization and operationalization of liberalization.

In this paper different categories of organization within the electricity industry are constructed in an attempt to define a clear conceptual framework for the economic liberalization of the various sectors of the economy. A conceptual framework to cope with the ongoing organizational dynamic of the electricity industry is proposed. The scientific

2In a former publication both authors have dealt extensively with this question. See Künneke et al (1994). (This publication is only available in Dutch.) 
challenge is how to deal simultaneously with both economic and political goals at the conceptual level. Economic goals are driven by the process of liberalization, whereas political goals are set in order to guarantee the traditional public tasks of the electricity industry. How can these different goals - often perceived to be in conflict with one another - be integrated in one theoretical framework for organizing the electricity industry? This question involves not only problems of organizational dynamics, but also problems of government regulation. Both problems will be dealt with in this paper.

The paper is structured as follows. The second part deals with the concept of public tasks; politicians see these as the main performance targets the electricity industry should meet, whatever the structure of the industry. The third part offers a conceptualization of the structure of the industry. Section four contains different models for this. Based on these models we develop, in section five, a first attempt at a conceptualization of liberalization. In section six we investigate the relationship between the structure of the industry and government regulation. Application of the conceptual framework is illustrated in section seven for the cases of the Netherlands, Germany, England and Wales, and France. The final part of the paper contains some concluding remarks.

\section{The concept of public task}

The public tasks of an industry can be defined as those aspects of the performance of an industry or of companies that serve a set of public goals as defined by politicians, and often enforced by governmental regulation. ${ }^{3}$ Traditionally, public involvement in the electricity industry is motivated by two types of arguments: economic and political.

The economic argument results upon a perceived market failure in the electricity industry, and is based on a number of economic and technical observations.

(1) Electricity is a basic good that cannot easily be substituted by other sources of energy. Given a very low price elasticity, market procurement of this good can easily result in suppliers behaving as monopolies. Public dominance is legitimized in the interests of securing a constant, safe and efficient supply of electricity for the nation without monopolistic pricing and investment.

(2) The production, transport and distribution of electricity are assumed to be natural monopolies. In the past, the industry was claimed to be a classic example of the persistence of economies of scale; because of cost advantages, national or regional utilities were allowed to enjoy monopoly positions in order to avoid welfare decreasing competitive investments.

(3) The supply of electricity is technically dependent upon highly specialized infrastructure: the transport and distribution grid. The development of this technical infrastructure is characterized by a very high degree of capital

${ }^{3}$ However, regulation is not always necessary to ensure the fulfilment of public tasks. asset specificity (see, eg Williamson, 1985). This means that initial investments in the grid drive their value only by virtue of a specific relation between the seller (ie the electricity producers) and the buyer (the end consumer or a market intermediary). Huge investments have to be made prior to any delivery of energy, and consequently before any cash flow. If one player decides to withdraw his commitment to the transaction (and he is legally allowed to do so), the investment costs will be lost, because there are no alternative players in the market. There may also be an incentive for one player to realize quasi-rents. These asset-specific investments are considered to be very risky in the absence of public intervention; public dominance is legitimized in the interests of reducing investment risks, and securing the development of an effective nationwide infrastructure. As a result, public intervention in effect regulates entrance to the grid.

(4) Electricity cannot easily be stored. To guarantee the technical and economic integrity of the system, supply and demand continually have to be kept in balance, whatever the actual delivery conditions, public interference is legitimized in the interests of securing an uninterrupted supply of electricity.

The second set of arguments supporting public dominance of the electricity industry are politically motivated. Many countries, even within the European Union, have a strong national interest in securing an independent supply of energy, thus avoiding a reliance upon foreign utilities. A safe and continuous supply of energy is a precondition for steady and prosperous economic development. For this reason, countries in Europe, and elsewhere, support and protect a strong national electricity industry.

The public dominance of the industry is also legitimized for socioeconomic reasons, in particular to support national industries. In Germany and the United Kingdom special regulatory arrangements ${ }^{4}$ have been used to stimulate the burning of domestic coal for generating electricity. In the Netherlands availability of national natural gas reserves forms one of the premises of national electricity production planning; gas fired power stations make up a significant part of the total generating capacity, partly as a result of political decisions. The Dutch government also fixed the price of electricity for nationally important industries, such as greenhouse market gardening, and the aluminium and chemical industries. The desired production techniques may be supported by stimulating appropriate technological innovations, for example the development of nuclear power in France. After Chernobyl, the Dutch government decided to build no more nuclear power stations, which in turn affected national scientific research in this area. Electricity pricing is also used as an instrument of social policy, for

${ }^{4} \mathrm{~A}$ classic example is the German Kohlepfennig, an additional tax on electricity consumption to subsidize the burning of German coal, making the price of German coal double the world market price. 
example by fixing low tariffs to protect low income groups, or to pursue a social disconnection policy for defaulters. ${ }^{5}$ Finally, the national electricity industry is an important provider of employment.

Environmental protection has recently been added to the electricity industry's list of public tasks. Without technological innovation, the large-scale generation and supply of electricity may have a significant impact on the natural environment. Reducing emissions from large-scale power stations has been part of Dutch environmental policy since the 1970s; improving fuel efficiency, the political choice of the mix of fuels to be burned, and energy saving measures, have been introduced as new environmentally motivated goals for the electricity industry. In the Netherlands, the government and the industry have also agreed to achieve significant reduction in energy consumption. To meet these targets, the distributors will have to cncourage consumers to use less electricity.

To summarize, the perceived market failure of the electricity industry has given rise to four main public tasks. First, protecting the consumer by providing electricity at low tariffs, and guaranteeing both quality and safety. Second, the assumed persistence of economies of scale in production, transport and distribution. Third, management of the grid to guarantee that investors recover their costs, and to ensure that the grid remains accessible to players in the industry. Fourth, safeguarding supply by maintaining a balance between economic and technical forces. Besides these economic arguments, socioeconomic and environmental arguments are used to legitimize public dominance of the industry.

It must be stressed that these public tasks are likely to change. Because of technical developments, economies of scale in production are less persistent than we thought only a decade ago; small-scalc electricity generation technologies have been developed that can already compete in terms of efficiency with big power stations. The degree of asset specificity of the grid is declining as the density of the grid and the number of players connected to it increase. Furthermore, socioeconomic preferences have changed, as has the political will to use electricity tariffs and investments as instruments of social and economic policy.

However, to explore the potential for liberalizing the electricity industry, it is necessary to account for these different categories of public tasks. Liberalization might affect these public tasks because they would then not be guaranteed by government regulation; a careful trade off has to be made between the political and economic desirability of enforcing these public tasks by government regulation in a liberal market. Liberalization is expected to enhance economic performance, whereas regulation appears to emphasize carrying out the public tasks. As a consequence, the structure of the electricity industry and the involvement of public authorities are strongly related, as evidenced by the link between liberalization and public tasks. To disentangle

5 Examples of this type of public involvement can be found in Belgium.
Table I Characteristics of basic coordinating systems

\begin{tabular}{|c|c|c|c|}
\hline $\begin{array}{l}\text { Coordinating } \\
\text { mechanism }\end{array}$ & $\begin{array}{l}\text { Unit of } \\
\text { decision making }\end{array}$ & $\begin{array}{l}\text { Mechanism } \\
\text { of allocation }\end{array}$ & $\begin{array}{l}\text { Dominant } \\
\text { ecomomic goal }\end{array}$ \\
\hline Market & Indi & Price setting & ity \\
\hline Net: & Group & & titability \\
\hline fierarchy & Public authority & Directive & National public interes \\
\hline
\end{tabular}

'The coordinating mechanisms are treated as Weberian 'ideal types' in order to cope conceptually with organizational dynamics.

this conceptuality, we first deal with each concept separately. In the next two sections, organizational models are proposed which cope with the concept of liberalization. The concept of government regulation is then discussed, and both concepts then brought together.

\section{Basic models of organization in the electricity industry}

Two steps are necessary in order to cope conceptually with the static and dynamic organization of the electricity industry. First, to define the basic mechanisms underlying the coordination of economic activities: and second to elaborate upon the structural features of the electricity industry. At the basic analytical level three systems for coordinating economic activities can be distinguished: markets, networks and hierarchies (Thompson et al, 1994; Dahl and Lindblom, 1953; Dahl, 1982). These systems differ from each other in three fundamental ways:

(1) the mechanism of economic decision making;

(2) the mechanism of allocation; and

(3) the goals of economic activities.

Table 1 lists these differences between the three systems.

In a market system decision making is completely individualized. Individual players, motivated by self-interest, are autonomous decision makers regarding their consumption and production of goods and services. The neoclassical price theory models this individual decision process with great formal elegance. Price setting governs the system, in which individual players compete against each other to achieve individual economic goals.

The network is characterized by a voluntary collective decision process among a group of players. Although all the players have identical property rights with respect to certain economic goods, none of them is able to change or capitalize their bundle of property rights without the approval of the other members of the group. In a network. players decide to cooperate voluntarily; planning by consensus becomes the primary mechanism for allocating goods and services. In this system, competition in the market system is replaced by consensus building, which reduces the degree of autonomy enjoyed by individual decision makers. The economic goals of a group can be described as collective profitability and continuity.

The third mechanism for coordinating economic activity is public authority. Here the decision mechanism is based on 
the presence of a public authority forcing the players to operate the system according to certain directives. Goods and services are allocated by a publicly dominated system of planning; the dominant economic goal being not individual or collective profitability, but the public interest. The electricity industry in European countries has traditionally been dominated by this third mechanism of hierarchical allocation.

At the level of basic economic institutions, reforming the electricity industry in European countries may be perceived a choice for or against a specific coordinating mechanism. In theory, all activities may be coordinated by one mechanism; in reality, though, all three coordinating mechanisms exist simultaneously in the electricity industry, although at any moment in time one of them is dominant. At the basic level, the actual reforms may be perceived as simply adding one or two more coordinating mechanisms to the dominant mechanism in order to facilitate economic transactions and other activities. This is what actually happens in many European countries; two or three mechanisms simultaneously coordinate transactions in order to bring about reform. On a theoretical level, industrial economic structures can be described as mixtures of different coordination systems, one of them being dominant. This results in a conceptualization with one dominating coordination system, to which, in the simplest case, one other system is added, giving nine different systems of coordination. This is illustrated in Table 2.

Each mixed model can be characterized as follows:

(1) In the coordinated free market the price setting mechanism is combined with specific agreements between market players. such as agreements on prices and market shares. An example of this kind of agreement in a market system is the cartel.

(2) In the controlled free market the autonomy of individual players is partly restricted by public authority, for example the right to export electricity, or to enter the grid.

(3) The liberalized coordination is characterized by a set of agreements partly implemented by the price setting mechanism, for example contracting out new generating capacity in the electricity industry.

(4) In a system of controlled coordination the public authority prescribes the norms and standards of the system which are to be attained by the players themselves, through consensus and agreement. An example of controlled coordination is the approval required from the Dutch government for the electricity plan made by the Dutch electricity production organization (Sep).

(5) The liberalized hierarchy uses the price mechanism in a system dominated by a public authority. An example of this coordinating mechanism is the application of price adjustments between the various divisions of a state dominated electricity company.

(5) The coordinated hierarchy is a system dominated by a public authority in which the players are allowed to decide certain issues themselves; an example in France is the agreement between EDF and GDF to open up new distribution areas.
Table 2 Pure and mixed systems for coordinating economic activities

\begin{tabular}{|c|c|c|c|}
\hline \multirow{2}{*}{$\begin{array}{l}\text { Added } \\
\text { coordinating } \\
\text { mechanism }\end{array}$} & \multicolumn{3}{|c|}{ Dominant coordinating mechanism } \\
\hline & Price & Agreement & $\begin{array}{l}\text { Public } \\
\text { authority }\end{array}$ \\
\hline Price & $\begin{array}{l}\text { Full free } \\
\text { market }\end{array}$ & $\begin{array}{l}\text { Liberalized } \\
\text { coordination }\end{array}$ & $\begin{array}{l}\text { Liberalized } \\
\text { hierarchy }\end{array}$ \\
\hline Agreement & $\begin{array}{l}\text { Coordinated } \\
\text { free market }\end{array}$ & $\begin{array}{l}\text { Full } \\
\text { coordination }\end{array}$ & $\begin{array}{l}\text { Coordinated } \\
\text { hierarchy }\end{array}$ \\
\hline Public authority & $\begin{array}{l}\text { Controlled } \\
\text { free market }\end{array}$ & $\begin{array}{l}\text { Controlled } \\
\text { coordination }\end{array}$ & $\begin{array}{l}\text { Full } \\
\text { hierarchy }\end{array}$ \\
\hline
\end{tabular}

It is theoretically possible to identify more organizational models, for example by defining not one but two additional mechanisms next to the dominant coordinating mechanism. However, this procedure is theoretically so complex that it becomes difficult to handle. In order to empirically understand the current reforms in European countries - as a first step towards operationalizing the economic structure of industrial sectors - it will be sufficient to concentrate on the theoretical extension of the models listed in Table 2.

By adding other structural features, the nine basic models can be expanded conceptually to cope with the empirical complexity of the organization of the electricity industry. However, adding more structural features does not affect the organizational classification in Table 2. At the conceptual level, models of sector organization cannot cope with political preferences for the structure of an industrial sector, so, in the next section, we expand the nine basic models by adding some structural features that seem to be relevant to the electricity industry. The extended models cope with structural features which may be significant for specifying the conditions impinging upon the organization of the industry. Our frame of reference is the neoclassical idea of the structure-conduct-performance paradigm, and neo-institutional economic theory.

\section{Extended models of organization in the electricity industry}

The structure of industrial sectors of the economy, such as the electricity industry, often displays many, rather complex features. In order to cope theoretically with this complexity it is necessary to specify some basic structural elements of the economic organization in the nine systems of coordination. The structural features we propose are based on a mixture of theoretical insights from different economic theories. The significance of these features and their different effects is discussed briefly in the following sections. Based on these features, the extended models are elaborated.

\section{Entrance restrictions}

Roughly speaking, three different types of entrance restrictions can be identified:

(1) natural barriers to entry caused by certain cost structures (economies of scale, economies of scope, learning effects, or geographically defined cost advantages); 
(2) artificial restrictions resulting from strategics adopted by the players;

(3) artificial restrictions authorized by the public authority.

The importance of restrictions to entry is emphasized in traditional (neo)classical economic literature on industrial organization. Traditional neoclassical theories identify different types of markets, such as full competition, monopolies and oligopolies, by distinguishing between the actual degrees of entry by competitors. In Baumol's theory of contestable markets - a different approach - the potential for entrance by new players under certain circumstances is assumed to influence economic behaviour (Baumol, 1982). In addition, entrance barriers have been a focal point of analysis in recent publications about the dynamic aspects of industrial organization (Baldwin, 1995).

\section{The need for information}

Economic allocation processes often take place on the basis of incomplete and asymmetric information. Neo-institutional economic theories deal with the impact of incomplete information on the allocation of economic goods. ${ }^{6} \mathrm{As}$ it is theoretically elaborated by principal agent theory and the transaction cost approach, economic transaction processes are strongly influenced by the availability of information and its distribution among the various players. Neoclassical markets assume a high degree of transparency. In the case of incomplete information, or information asymmetry, specific contractual arrangements are needed to reduce economic risks. Pechman (1993) demonstrates that the management of information flows is an important feature of the organization of the electricity industry. He argues that market power in this industry is based, among other things, on the control of relevant information flows. Power pools can turn out to be information cartels, and information asymmetry makes these difficult to control, even by public regulators (Pechman, 1993, pp 68, 69):

the utility, by creating organisations that are beyond a state regulatory commission's control, is able to control information required for effective regulation and the development of efficient markets. The vehicle by which utilities gain this market power is what I call an information cartel.

It can be argued that different institutional settings can be identified by the way they handle the need for information of economic players. Generally, three different cases can be identified:

(1) full transparency;

(2) information asymmetry is dealt with by voluntary exchange of information;

(3) information asymmetry is dealt with by (public) control.

${ }^{6} \mathrm{~A}$ good overview of this theoretical approach is given by Eggertsson. 1990.

\section{Governance structures}

Williamson (1985) distinguishes four different types of governance structures:

(1) Market governance: all relevant transaction parameters are known to the players, and there are no transaction specific investments. This is a situation characterized by little or no uncertainty, and economic activities can be organized by spot market transactions.

(2) Trilateral governance: uncertainties about the future state of the world are significant, and players are also engaged in asset specific investments, which increases economic risks. In this situation, pure market arrangements are not satisfactory because of the threat of opportunistic behaviour by third parties which seek to realize quasi-rents. ${ }^{7}$ This uncertainty can be dealt with by 'third party assistance (arbitration) in resolving disputes and evaluating performance' (Williamson, 1985 , p 75). By incorporating this third party assistance in a contractual arrangement, transactions can be made in the marketplace. In the electricity market an independent regulator might operate like third party assistance, facilitating contractual arrangements within a market regime.

(3) Bilateral governance: a specialized governance structure in which the participating players retain their economic autonomy in a situation characterized by a high degrec of asset-specific investment and uncertainty (Williamson, 1985, p 75). Transactions take place in a market regime, but specific bilateral contractual arrangements have to be made to cope with the possibility of opportunistic behaviour. Players adopt long-term bilateral contractual arrangements which, if necessary, are subject to permanent revision. Because both market parties are locked into the transaction by specific investments, none of them has the opportunity to take advantage of the dependency of the other. For example, in the liberalized Norwegian electricity market a substantial number of producers, distributors, and traders continued their relationship with their traditional contracting partners after liberalization; even spot market prices remained significantly different from the contract prices. An explanation might be that both market parties had built up a high degree of mutual asset specific knowledge and confidence, which would be lost when changing contract partners.

(4) Unified governance: hierarchical coordination of economic activities by vertical integration. Unified governance is transaction cost efficient in a situation characterized by highly asset specific investment, in combination with a high degree of uncertainty. Although this unified governance is often achieved in

\footnotetext{
${ }^{7}$ Quasi-rents are economic surpluses which are captured from other actors as a consequence of dependencies caused by asset-specific investments see Williamson (1985)
} 
Table 3 Different market based organizational models

\begin{tabular}{|c|c|c|c|}
\hline $\begin{array}{l}\text { Market model } \\
\text { features }\end{array}$ & $\begin{array}{l}\text { Full } \\
\text { free market }\end{array}$ & $\begin{array}{l}\text { Coordinated } \\
\text { free market }\end{array}$ & $\begin{array}{l}\text { Controlled } \\
\text { free market }\end{array}$ \\
\hline Allocation mechanism & Price setting & $\begin{array}{l}\text { Price setting } \\
\text { supplemented by agreement }\end{array}$ & $\begin{array}{l}\text { Price setting } \\
\text { supplemented by } \\
\text { public authority }\end{array}$ \\
\hline Dominant unit of decision making & \multicolumn{3}{|c|}{ Individual player } \\
\hline Goal of economic activity & \multicolumn{3}{|c|}{ Individual profitability and contimuity } \\
\hline Entry restrictions & No restrictions & Restrictions by agreement & $\begin{array}{l}\text { Artificial restrictions } \\
\text { by public authority }\end{array}$ \\
\hline Information needs & Full transparency & \multicolumn{2}{|c|}{ Information asymmetry } \\
\hline Contractual relations & Market governance & Bilateral governance & Trilateral governance \\
\hline Ownership structure & \multirow{2}{*}{$\begin{array}{l}\text { Privale property } \\
\text { Open borders }\end{array}$} & Common property & Public property \\
\hline International trade & & $\begin{array}{l}\text { Restricted by } \\
\text { agreement }\end{array}$ & $\begin{array}{l}\text { Restricted by } \\
\text { public authority }\end{array}$ \\
\hline
\end{tabular}

private sector firms, we will concentrate in this article on the specific case of unified governance enforced and controlled by a public authority.

\section{Ownership}

Property rights theory literature suggests that the structure of ownership influences economic performance and allocation processes. ${ }^{8}$ Generally, three different types of ownership structures can be identified:

(1) private ownership, in which all relevant aspects of property rights are held by private players;

(2) common ownership, in which a group of private players takes the relevant allocation decisions, for example in an industrial cartel;

(3) state ownership, in which a public authority controls all allocation decisions, which in turn might be under political control.

In the discussion about restructuring European electricity markets the change from state ownership to private ownership is a recurrent issue.

\section{International trade}

Granting possibilities for international trade between individual electricity producers, distributors, and traders is assumed to stimulate efficiency in the industry: allowing international trade threatens the monopoly position of national traders in electricity. Three different possibilities can be identified: (1) autarky; (2) restricted foreign trade; and (3) unrestricted foreign trade.

\section{The extended models}

Some structural features are partly assumed, such as information needs and the persistence of natural or artificial barriers to entry. Other features can be interpreted as the result of economic behaviour under certain conditions, such as ownership structures and various contractual relations. The persistence of barriers to entry can also be interpreted as the result of specific strategies adopted by economic

${ }^{8}$ A classic overview article is De Alessi (1980). players. Although this list of features of the economic order is both known and well accepted in the literature, it would appear that there is no coherent theoretical foundation. We believe that our categorization of different systems of coordination, as presented in the preceding section, might be a first step towards filling this theoretical gap.

The structural features mentioned above can serve to define our nine models of organization. The first set of organizational models is based on the market as the dominant coordinating mechanism. The three different market oriented coordination systems may be defined by these additional features, as shown in Table 3.

Table 3 lists the three market based organizational models, which are defined logically according to the structural features discussed above. The dominant allocating mechanism is price-setting, combined with voluntary agreements (the network approach) in the coordinated free market, or public regulation (the hierarchy approach) in the controlled free market. Because of the dominance of the price mechanism, the individual player is the basic unit of decision making. In a coordinated free market, decisions made by individual players are conditioned by agreements with other players, or by public regulation if the free trade market is controlled. The same holds true for the economic goals of the system; individual profitability and continuity is dominant, but is conditioned by agreements in a coordinated free market, and by public regulation in a controlled free market. The wider scope of the italicized cells in Table 3 indicates where it is not possible to link the features to specific economic regimes. For example, public ownership may occur in all three types of market based organizational models; even a full free (neoclassical) market can function with public sector economic players, in case their economic goals are determined entirely by profitability and individual continuity. Other additional features appear to have similar 'degrees of freedom' with respect to the different economic systems. Because of this ambiguity, the different organization models of the electricity industry can only serve as examples of industrial organization, in which the various structural features display a certain theoretical logic.

The network and authority based models can be defined in the same way - see Tables 4 and 5 . In both tables the cells have been logically defined. 
Table 4 Different network based organizational models

\begin{tabular}{|c|c|c|c|}
\hline $\begin{array}{l}\text { Network model } \\
\text { features }\end{array}$ & $\begin{array}{l}\text { Liberalized } \\
\text { coordination }\end{array}$ & $\begin{array}{l}\text { Full } \\
\text { coordination }\end{array}$ & $\begin{array}{l}\text { Controlled } \\
\text { coordination }\end{array}$ \\
\hline Allocation mechanism & $\begin{array}{l}\text { Agreement, supplemented } \\
\text { by price setting }\end{array}$ & Agreement & $\begin{array}{l}\text { Agreement, supplemented by } \\
\text { public authority }\end{array}$ \\
\hline Dominant unit ol decision making & \multicolumn{3}{|c|}{ Group } \\
\hline Goal of economic activity & \multicolumn{3}{|c|}{ Collective profitability and continuity } \\
\hline Entry restrictions & \multicolumn{2}{|c|}{ Restrictions by agreement } & \multirow{3}{*}{$\begin{array}{l}\text { Artificial restrictions by public } \\
\text { authority } \\
\text { Enforced information exchange } \\
\text { Trilateral governance }\end{array}$} \\
\hline Information needs & Full transparency & Voluntary information excliange & \\
\hline Contractual relations & Market governance & Bilateral governance & \\
\hline Ownership structure & Private property & Common Property & Public propery \\
\hline International trade & \multicolumn{2}{|c|}{ Restricted by agreement } & Restricted by public authority \\
\hline
\end{tabular}

Table 5 Different hierarchical organizational models

\begin{tabular}{|c|c|c|c|}
\hline $\begin{array}{l}\text { Hierarchy model } \\
\text { features }\end{array}$ & $\begin{array}{l}\text { Liberalized } \\
\text { hierarchy }\end{array}$ & $\begin{array}{l}\text { Controlled } \\
\text { hierarchy }\end{array}$ & $\begin{array}{l}\text { Full } \\
\text { hierarchy }\end{array}$ \\
\hline Allocation mechanism & $\begin{array}{l}\text { Public authority, supplemented } \\
\text { by price setting }\end{array}$ & $\begin{array}{l}\text { Public authority, supplemented } \\
\text { by agreement }\end{array}$ & Public authority \\
\hline Dominant unit of decision making & \multicolumn{3}{|c|}{ Public authority } \\
\hline Goal of economic activity & \multicolumn{3}{|c|}{ Public interest } \\
\hline \multirow{2}{*}{ Entry restrictions } & \multicolumn{2}{|c|}{ Conirolled entrance } & \multirow{4}{*}{$\begin{array}{l}\text { Artiticial restrictions by public } \\
\text { authorty } \\
\text { Enforced information exchange }\end{array}$} \\
\hline & based on oulput & based on agreement & \\
\hline Information needs & $\begin{array}{l}\text { Transparency, where price } \\
\text { setting is employed }\end{array}$ & Voluntary information exchange & \\
\hline Contractual relations & Bilateral contracting & Trilateral contracting & \\
\hline Ownership structure & Private propery & Common property & Public propery \\
\hline International trade & \multicolumn{3}{|c|}{ Resiricted by puhlic authority } \\
\hline
\end{tabular}

In the network based models the group is the dominant unit of decision making, allowing price setting mechanisms to be agreed upon voluntarily by the group in a system of liberalized coordination. In a system of controlled coordination voluntary agreement by the group is conditioned by public regulation. Again, the italicized cells represent features which cannot be uniquely attributed to just one of the organizational models.

In the authority based models, the public authority is the dominant unit of decision making, allowing price setting in a liberalized hierarchy, or voluntary agreement in a coordinated hierarchy as additional coordinating mechanisms.

It appears to be difficult to attribute the features specified in the extended organizational models to one specific regime; they even show up in very different institutional settings. For example, publicly enforced 'entry restrictions' appear in controlled free markets, controlled coordinations, and full hierarchies. Contractual relations, which can be the same in different dominant coordination mechanisms, are another good example. If empirical comparisons between different national institutional regimes are only based on these criteria they become rather fussy; the advantage of our classification scheme is that we are able to theoretically define a distinctive criterion for the identification of different coordination systems.

\section{The concept of liberalization}

Using the models of sector organization it is possible to define the concept of liberalization as:
(1) a change in the dominant coordination system from hierarchy to network, or from network to price mechanism; and/or

(2) a change in the additional coordination system - which a constant dominant coordination system - from hierarchy to network, or from network to price mechanism.

Changes in additional coordination systems can be operationalized as a change in some additional feature of the organization of the sector. A change in the dominant coordination system results in a completely new organizational model of the sector.

Table 2 illustrates the principle underlying both types of liberalization. The first type is illustrated by a change in the dominant coordinating mechanism from the top right to the top left of the table (from public authority, via agreement, to price). The second type of liberalization, represented vertically, illustrates the dynamic from the bottom to the top of each column.

Distinguishing between these two types of liberalization allows us to understand the processes of liberalization in relation to the actual structure of the electricity industry in different countries. Take, for instance, the Netherlands and France. The actual structure of the Dutch electricity industry can be described as a system of 'controlled coordination' because agreement is dominant, but strongly conditioned by the public sector. Dutch liberalization may result in a system of 'full coordination', or even 'liberalized coordination'. In France the actual structure of the electricity industry can be described as a system of 'full hierarchy'; 
here, liberalization may result in a system of 'coordinated hierarchy', or 'liberalized hierarchy'. So, in both countries the direction of liberalization is the same, but the kind of liberalization is quite different, owing to differences in the organizational structure of the industry. We look at these examples in more detail below.

\section{Organizational models and styles of government regulation}

With the exception of the pure hierarchial model, all models of industrial organization are, to a certain degree, liberal. However, the real potential for liberalization is theoretically determined by two related factors: the economic and technological limits of electricity as a good, and national political decision making. For example, the scope for trading in electricity is restricted by accessibility to the grid, which is not only a matter of economic rationale, but also of political choice. Both these factors can only be partly included in the theoretical discussion, because the actual organizational structure will always be partly determined by political considerations.

The question of the possibilities for liberalizing the electricity industry can therefore be recast to address the content and scope of government regulation. Only in the pure hierarchical model are the structure, functioning and performance of the industry completely determined and controlled by public authority, the two coinciding almost entirely. In the other eight models the content and scope of public authority is ultimately a matter of political choice. The question which then arises is: whether the relationship between industrial organization and government regulation can be specified at the conceptual level. We think it can, if the basic assumption about the role of the public authority in different organizational models is taken as the starting point. It will be argued that the type of government regulation is determined by the type of industrial organization. Let us start with the pure models of industrial organization.

In a full free market the role of the public authority is subordinate to that of other players in the industry; the full free market is dominated by individual exchange relations between equivalent players. These relations should not be affected by government regulation, because this would disrupt the functioning of the free market. So, for this reason the public authority is subordinated to the other actors. In a system of full coordination the role of the public authority is equivalent to that of the other players; agreement between players, of which the public authority is one, is the dominant organizing principle. In such a system, the authority is free to make agreements with other players. In a system of full hierarchy the public authority is in a dominant position to the other players in the industry; the public authority is able to enforce its will.

The type of industrial organization, therefore, determines the role of the public authority, and it can be assumed that this role dictates the style of public regulation. The style of public regulation can be defined by the degree of coerciveness; in a pure hierarchical organization the style of regulation is coercive by definition, whereas in a neoclassical free market the style of regulation works to keep the level of coercion to a minimum. Three basic styles of regulation can be identified in order to theoretically define the scope of regulation in each organizational model. ${ }^{9}$

(1) The facilitating style: the government only lays down conditions for the functioning of the electricity industry.

(2) The initiating style: the government encourages the industry to develop in a certain direction.

(3) The enforcing style: the government forces the industry to develop in a certain direction. ${ }^{10}$

In theory, a public authority does not have to take its role within a sector of the economy into account when setting regulations. In all three roles, facilitating, initiating and enforcing styles are all possible. However, to achicve effective regulation the public authority must choose a style of regulation which matches its actual role; so, the relationship between its role and its style of regulation is characterized more by probability than by inevitability.

The style of government regulation, like industrial organization, may be dynamic. Depending upon whether the level of coercion is decreasing or increasing, two main types of change may be observed: (1) deregulation, from enforcing to facilitating; and (2) reregulation, from facilitating to enforcing.

The style of government regulation can be identified by the object of government regulation. Taking the neoclassical structure-conduct-performance paradigm as a starting point, both the structure and the conduct of the industry are perceived to be the objects of government regulation. The performance of the sector can be interpreted as the result of regulating structure and/or performance.

The structure of industrial organization, as an object, has been elaborated upon in previous parts of this paper. The following structural features can be regulated:

(1) the mechanism of allocation;

(2) entrance restrictions;

(3) contractual relations;

(4) ownership;

(5) access to the market.

As an object of government regulation, conduct concerns the production of electricity: here, regulation may influence the fuel mix, production technologies, the environmental impacts of electricity generation, the security of supply, and tariffs. It also concerns transport and distribution: here, regulation controls transport, technical delivery, entrance conditions to the grid, and tariffs. Regulation affects trading in electricity, security of supply, environmental management by the end users, tariffs, and the conditions governing import and export. These are just some examples of conduct

\footnotetext{
${ }^{9}$ Actually, coerciveness should be viewed as a continuum, allowing more than three 'positions' to represent different styles of regulation.

10These styles of regulation are a variation on the typology often proposed in the literature. Sec, for example, Mitnick (1980).
} 
Table 6 Industrial organization and regulation

\begin{tabular}{lll}
\hline $\begin{array}{l}\text { Industrial } \\
\text { organization }\end{array}$ & $\begin{array}{l}\text { Dominant style } \\
\text { of regulation }\end{array}$ & $\begin{array}{l}\text { Dominant object } \\
\text { of regulation }\end{array}$ \\
\hline $\begin{array}{l}\text { Full free market } \\
\text { Coordinated market } \\
\begin{array}{l}\text { Controlled market } \\
\text { Liberalized coordination }\end{array}\end{array}$ & Facilitating & Structure \\
$\begin{array}{l}\text { Full coordination } \\
\text { Controlled coordination } \\
\text { Liberalized hierarchy }\end{array}$ & $\begin{array}{l}\text { Facilitating, } \\
\text { initiating }\end{array}$ & $\begin{array}{l}\text { Sonduct } \\
\text { initiating and } \\
\text { enforcing }\end{array}$ \\
$\begin{array}{l}\text { coordinated hierarchy } \\
\text { Strict hierarchy }\end{array}$ & & \\
\hline
\end{tabular}

regulation, which could be described and expanded upon in more detail.

Theoretically, the object of government regulation consists of the structure and economic activities of the electricity industry: production, transport/distribution, and trade. In reality these activities are often recognized as being subsectors of the electricity industry, each displaying different opportunities for liberalization, and are consequently distinct objects of government regulation.

The theoretical relationship between industrial organization on the one hand, and the style and object of regulation on the other hand, can be specified theoretically, as shown in Table 6.

It should be noted that in Table 6 the organizational models are related to the dominant style of regulation and object of regulation. The relationship is a hypothetical one, based on theoretical rather than empirical arguments. In organizations dominated by the price mechanism, government can only take on a facilitating role by guaranteeing certain structural preconditions for the autonomous functioning of the market. In these market based models the primary objective is to optimize the functioning of the free market, which is only possible because the market players' motives are primarily economic.

In the network based models the primary objective is to optimize self-governance within the group by facilitating and initiating voluntary agreement and cooperation. Besides a facilitating style of regulation - the organizational structure being the primary objective - it may be appropriate to initiate certain developments. For example, a change in organizational structure might lead to a new working stye within the self-governing group.

Public dominance in the hierarchy models makes the choice of regulation style irrelevant in these cases; the public authority can do what it likes, always being able to enforce its will upon the industry.

\section{National liberalization programmes}

The classification scheme developed in this article can be used to analyse different national liberalization programmes. As we shall demonstrate in this section, it is possible to identify different national priorities in the reorganization of the industry, and to determine different possible future directions of the liberalization process. To illustrate this, the cases of the Netherlands, Germany, England and Wales, and France will be subjected to our extended models of coordination regimes. This description is only very brief, and is intended to demonstrate the possibilities for comparing the different styles of liberalization in these countries. A more detailed analysis is needed, and is the subject of a new research project.

\section{The Netherlands}

The current structure of the industry ${ }^{\prime \prime}$ can be described as controlled coordination - a regime dominated by agreements, with public authority supplying an additional coordination system. Producers and distributors cooperate mainly by mutual agreement, but some important features of the Dutch electricity market are brought about by government regulation.

Market entrance There are entrance restrictions for 'electricity only' producers. Among other more technical regulations, producers must provide a minimum of at least 2.5 MW installed capacity. However, there are no entrance restrictions to the decentralized electricity generation market for distributors (up to $25 \mathrm{MW}$ ), and to companies in other industries which also generate electricity (without an upper capacity limit). Distribution and trading in electricity is strictly regulated by public permits.

Information exchange The exchange of information is mainly voluntary, although this is to a certain extent compelled by the Electricity Act, which stipulates the pooling of electricity generation. Distribution and trading in electricity is regulated by a system of maximum tariffs negotiated between the industry and the Ministry of Economic Affairs, and both prices and the service offered by the various traders are highly transparent. ${ }^{12}$ Investments in generating capacity and transmission lines (as far as 'electricity only' producers are concerned) are coordinated by a national planning system, and set down in the biennial electricity plan (Electriciteitsplan). This electricity plan is agreed by the electricity industry and has to be approved by the central government. Decentralized capacity (mainly industrial (HP) is not included in this system of national planning.

Ownership Ownership lies with the public sector: although almost all electricity utilities are legally private corporations, the shareholders are all public authorities. Contractual relations are trilateral, or even unified, because core

\footnotetext{
1'For a more detailed description of the legal structure of the Dutch electricity market see Huygen (1995). The description of the Dutch case is based on the market structure as before the publication of a policy note of the Dutch government for a further liberalization of this sector (Derde Energienota, 1996). The consequences of this policy note are not clear at the date of submission of this article.

$12 \mathrm{An}$ exception being the tariffs for giant industrial consumers.
} 
contractual parameters (like tariffs) are determined centrally by the pool.

International trade The national pool (Sep) in effect dominates international trade, although legally only distributors are excluded from international trade.

The present system for coordinating the Dutch electricity industry is an interesting combination of a network dominated approach - supplemented by governmental control (and therefore classified as "controlled coordination') - and elements of competition between central, 'electricity only' generating companies and decentralized producers. During the last few years it has become evident that this gives rise to an unstable institutional framework. Decentralized CHP has proved to be very competitive compared to the traditional, large-scale producers and has, unexpectedly, gained a market share of more than $20 \%$, leaving the central generating utilities with the costs concomitant with increasing excess capacity. Whereas the reforms were initiated to improve coordination between the various players in the industry and the supervision of government, the introduction of a less regulated market niche for decentralized production resulted in an unstable industrial organization. Two possible developments might occur. First, 'liberalized coordination' could be introduced to maintain the network based regime, while at the same time introducing some price-coordinated elements, such as price-based competition for new generating capacity and competition for distribution area franchises. However, to stabilize this regime institutionally, decentralized generation would have to be integrated into the national electricity plan. Second, the dominant coordination system could be transformed into a price-led system of allocation. A coordinated free market would fit well into the Dutch tradition. in which market players are used to cooperating on a voluntary basis with the government and among each other. ${ }^{13}$ The problem, however, is whether market players are prepared to compete against each other in the market place, as there is a long standing tradition of mutual cooperation which is difficult to overcome. By the end of 1995 the structure of the industry will be evaluated by the Dutch government and by Parliament. At the moment, the outcome of preparatory discussions on the choice between the two alternatives is still open.

\section{Germany}

The German electricity industry fits into the category of full coordination. The German federal government has only very limited influence over the industry, and this is mainly concerned with supporting the present institutional structure. The Länder and municipal authorities have slightly more powers of regulation: for example, for ensuring that there is sufficient investment in new capacity (the Energieaufzichtsbehörde of the Länder), and for issuing mu-

13The instability of the Dutch institutional framework is elaborated upon in more detail by Künneke (1995). nicipal permits for distribution area franchises. Apart from this limited degree of pubic control, voluntary coordination between players in the industry clearly dominates, even as an additional coordination mechanism.

Market entrance The market is shared out between players in the market by private law contracts which guarantee regional monopolies ('demarcation contracts'). In addition, electricity utilities are required to have a concession for the regional or local authorities to conduct business. These concessions and demarcation arrangements, which have a maximum term of 20 years, close the market against uncontrolled entrance. There are some independent power generating companies which receive a fixed retail price for electricity delivered to the National Grid, again based on private-law contracts.

Information exchange The exchange of information is voluntary; there is no national system of capacity planning, nor are there publicly imposed power pools. Tariffs are transparent.

Contractual relations Contracts are long term, and can be classified as forms of bilateral governance.

Ownership structure The pattern of ownership is diverse; mixed private-public ownership dominates, but there are also both privately and publicly owned utilities.

International trade There are no government restrictions on international trade, but only the nine biggest producers and distributors are active in cross-border trade.

The institutional structure of the German electricity market is quite stable, having obvious roots in the structure of the federal state. Players in the market are largely autonomous; the regional and federal authorities act mainly to support the functioning of the network. On the national German and European level there seems to be a political preference for a more market oriented structure, but it is not clear whether this will lead to the market, rather than the network, being the dominant coordination mechanism. It is to be expected that the price mechanism will become more significant as an additional coordination system, for example through the introduction of a tendering system for new generating capacity. This might imply that the generation sector will increasingly resemble a liberalized coordination system. but a shift towards the price mechanism as the dominant regime would require the application of German antitrust law to the electricity utilities to preclude private-law contracts. Although some thought has been given to this, the current operating mechanisms within the industry would not appear to support such significant changes to the institutional structure.

\section{England and Wales}

In these countries the structure of the electricity industry falls into the category of a controlled free market, the dominant object of government regulation being the market 
structure. Public regulators are granted the authority to support a market structure which allows for a sufficient degree of competition. Being natural monopolies, transport and distribution are heavily regulated, whereas generation and trade are predominately open to price coordinated transactions. All electricity producers have to sell to an independent pool, from which all suppliers must buy power. However, individual 'contracts for different' between producers and suppliers are allowed, and, as there is still a group of captive customers. ${ }^{14}$ prices for these consumers are regulated.

Market entrance Entrance to the electricity generation market is subject only to non-discriminatory technical restrictions; however, the publicly owned Nuclear Electric enjoys a guarantced market share. The trade in electricity is subject to some service and technical obligations, but is otherwise freely accessible.

Information needs To maintain sufficient market transparency pool prices are published daily, as are charges for using the transmission and distribution system. This amounts to a system of compulsory information exchange.

Contractual relations All activities handled directly by the pool can be described as market-governed arrangements. ${ }^{15}$ However, more than $90 \%$ of all electric power transactions are hedged by 'contracts for difference'; these contracts bind suppliers and producers for a longer period in order to reduce the risk of price fluctuation, and can be described as 'bilateral'.

Ownership structure The electricity industry is fully privatized, except for Nuclear Electric. ${ }^{16}$

International trade There are no restrictions on international trade, but there are technical difficulties associated with the transport of electricity from and to the Continent. Besides trade on the British mainland with Scotland, there is some trade with France.

The structure of the electricity industry in England and Wales is still evolving, with an obvious political preference for a market oriented structure. Liberalization and privatization were introduced simultaneously, resulting in the need for strong government intervention to ensure a sufficient degree of competition while guaranteeing a minimum standard of service and protection for captive customers. The nuclear power industry is an exception not only because it is publicly owned, but also because it has a guaranteed market share. There seems to be the political will to develop this industry into a coordinated free market, in which the market structure is the main object of govern-

\footnotetext{
${ }^{14} \mathrm{It}$ is planned that by 1998 all customers will have free market access. 15 However, with the pool as an independent third party between buyers and sellers, these activities also display some characteristics of trilateral governance.

16Recently. firm plans have been put forward to privatize Nuclear Electric.
}

ment regulation. However, if this government regulation is not effective, it may evolve into a liberalized coordination' regime in which private sector agreements - either formal or informal - determine market entrance, international trade, and the exchange of relevant information about the market. An effective anti-trust policy is therefore badly needed to maintain the market based organizational structure.

\section{France}

The French clectricity market is a textbook case of a nearly full hierarchy. The dominant object of government regulation is the structure and conduct of the industry. The central government has a strong position in the industry, supporting, initiating and enforcing developments mainly in accordance with its own political leanings - the decisive introduction of the nuclear power programme being an example.

Under present conditions Electricité de France (EDF) has a monopoly position, and there are no possibilities for third parties to enter the market. International trade is restricted by government regulation, and the industry is in public ownership. Being fully vertically integrated, all vital contractual relations are internalized within a unified EDF governing body. Owing to the specific structure of the industry, the information required by third parties is mainly limited to tariffs and service conditions, which are periodically published. The present system can be considered to be very stable; the only serious threat seems to be from the liberalization movement within the EU.

Taking into account the French preference for strong public control over the electricity industry, the possibilities for liberalization will have to be realized within the context of public control as the dominant coordination system. Development towards a liberalized hierarchy, including some price coordination, is to be expected. The French proposal for the introduction of a single buyer handling all international trade within the EU would be a step in this direction.

\section{Conclusion}

In this article we develop a theoretical conceptualization of different systems for coordinating industrial activities within sectors of the economy. Three pure and six mixed coordination systems are identified, and described in more detail using additional structural features. The main distinguishing factor is the choice of one of three different allocation systems (the price mechanism, voluntary agreement and governmental hierarchical authority) as a dominant or additional system. Based on this conceptualization, it is possible to operationalize the concept of liberalization as a change in the dominant or the additional coordination system.

As a second step, we discuss the nature of the relation between different modes of industrial organization and different types of government regulation. In the discussion about market reforms, the challenge is to find an optimal relationship between liberalization of the organization of 
the industry and the extent of government regulation. The reforms in the electricity industry cannot be dealt with only as an economic issue because politicians consider the industry to be responsible for certain public tasks. For this reason there are limits to liberalization, which strongly depend upon the degree to which the industry is expected to fulfil these public tasks. By considering the optimal national structure of the electricity industry in a specific national setting, a trade off has to be made between the stimulation of economic performance - which might be expected to coincide to some extent with liberalization of the industry - and carrying out various public tasks requiring government intervention.

By conceptualizing the notion of liberalization, this becomes theoretically distinct from the issue of privatization and regulation. As we argue in this article, liberalization deals with the choice of a dominant and additional coordination system. Privatization, as a change of ownership structure, is independent of this choice. Concerning the regulation of the electricity industry to guarantee various public tasks, we discussed above that there is some degree of correlation between different types of liberalization and regulation. It appears that liberalization leads under certain circumstances to a greater need for regulation - for example in the England and Wales case.

As a third step, the classification scheme is illustrated by applying it to four countries (the Netherlands, Germany, England and Wales, and France). The concept turns out to be useful in describing different organizational structures in the electricity industry, and in specifying the different degrees of liberalization already realized. Different national policy priorities are identified, and, as illustrated by the four above-mentioned countries it is demonstrated that liberalization takes on very different meanings in different national settings. By taking account of these national approaches to organizing the electricity industry, we can assess future liberalization policies. However, the optimal relationship - according to economic standards - between liberalization and public involvement can ultimately only be answered empirically.

\section{Acknowledgements}

The authors wish to thank Steven Thomas, Science Policy Research Unit, University of Sussex, for his helpful comments on an earlier version of this article.

\section{References}

Baldwin, J R (1995) The Dynamics of Industrial Competition: A North American Approach Cambridge, MA

Baumol, W J (1982) 'Contestable markets: an uprising in the theory of industrial structure' American Economic Review 72 1-15

Dahl, R A (1982) Dilemmas of Pluralist Democracy: Autonomy Versus Control Yale University Press, New Haven

Dahl, R A and Lindblom, C E (1953) Politics, Economics, and Welfare Harper \& Row 1963

De Alessi, L (1980) 'The economics of property rights: a review of the evidence' Research in Law and Economics $1-47$

Eggertsson, T (1990) Economic Behaviour and Institutions Cambridge University Press, Cambridge

Iluygen, A E H (1995) Electricity Regulation in the Netherlands Leiden

Künneke, R W (1995) 'The Dutch struggle for a stable institutional framework in the electricity market' in Olsen, $\mathrm{O} \mathrm{J}$ Competition in the Electricity Supply Industry: Experience from European and the United States Copenhagen, $181-206$

Künneke, R W, Manders, A M P and Arentsen, M J (1994) De positie van de Nederlandse nutshedrijuen in een liberale Europese markt [The Position of the Dutch Utility Sector in a Liberal European Market] Faculty of Public Administration and Public Policy, Enschede

Mitnick, B M (1980) The Political Economy of Regulation: Creating, Designing and Removing Regulatory Forms New York

North, D C (1981) Structure and Change in Economic History W W Norton, New York

Pechman, C (1993) Regulating Power: The Economics of Electricity in the Information Age Boston, MA

Thompson, G, Frances, J, Levacic, R and Mitchel, J (eds) (1994) Markets Hierarchies and Networks: The Co-ordination of Social Life Sage, London

Williamson, O E (1975) Markets and Hierarchies The Free Press, New York

Williamson, O E (1985) The Economic Institutions of Capitalism The Free Press, New York 